\title{
Wokół książki Badanie polityki zagranicznej państwa - odpowiedź na recenzję Romana Kuźniara ${ }^{1}$
}

Zamieszczona w czasopiśmie naukowym „Sprawy Międzynarodowe” recenzja pracy Badanie polityki zagranicznej państwa przygotowanej pod moją redakcją przez badaczy stosunków międzynarodowych z głównych ośrodków uniwersyteckich w Polsce jest przykładem braku zrozumienia funkcji recenzji w naukach społecznych.

Należy zauważyć, że w przeciwieństwie do nauk ścisłych badacze nie mają tu możliwości empirycznego testowania swoich hipotez i teorii, nawet jeśli stosują klarowne procedury badawcze zgodne z przyjętą metodologią. Osobliwości nauk społecznych - jak pisał przed laty Stanisław Ossowski ograniczają możliwość pełnego poznania, m.in. w związku z utrudnionym dostępem do adekwatnych danych empirycznych. Powoduje to, że badacz nie jest w stanie sformułować wyczerpującego objaśnienia teoretycznego. W przezwyciężeniu tej strukturalnej niedogodności pomagają dyskurs i aktywna debata oraz krytyka naukowa. Konkurencja, wymiana poglądów i weryfikacja pozwalają zgłębiać, dopracowywać oraz przeformułowywać wnioski, hipotezy i teorie, a tym samym przezwyciężać ograniczenia poznawcze człowieka. Są to naturalne procedury postępowania badawczego, które warunkują postęp naukowy rozumiany zarówno poziomo (ilościowy przyrost badań), jak i pionowo (nowe konceptualizacje, hipotezy, teorie). Krytyka naukowa $\mathrm{w}$ formie recenzji to nic innego jak specyficzna forma badania w oparciu o uznane w danej dziedzinie procedury i metodologie.

Recenzja Profesora Kuźniara nie spełnia kryteriów krytyki naukowej, ponieważ wykazuje brak zrozumienia dla specyfiki nauk społecznych, których cechami są dyskurs i wymiana poglądów z zachowaniem dwóch zasad - bona fides i sine ira et studio. Przede wszystkim zawiera ona wyłącznie wyraziste

1 R. Kuźniar, Edward Haliżak (red.), „,Badanie polityki zagranicznej państwa”, Rambler, Warszawa 2018, „Sprawy Międzynarodowe” 2018, t. 71, nr 2, s. 177-184. 
wartościujące sądy ad personam z użyciem całej gamy przymiotników i określeń o jednoznacznie negatywnym wydźwięku, mających jednak niewiele wspólnego z istotą oceny naukowej i standardami dyskursu naukowego (zob. sformułowania o hiszpańskiej oberży i ornitologii). W recenzji nie znajdziemy żadnego odniesienia do tego, co stanowi o specyfice sformułowanego we wstępie problemu badawczego i jak jest on definiowany w badaniach polityki zagranicznej. Nie ma w niej nic na temat zaproponowanej metodologii i metod badawczych (np. modelowania). Ani słowem nie wspomniano, jak recenzowana praca odnosi się do teorii polityki zagranicznej i teorii stosunków międzynarodowych. Profesor nie odwołał się też do żadnej zagranicznej ani krajowej publikacji w tej dziedzinie.

Problem jest jednak znacznie bardziej poważny, ponieważ Autor recenzji zdaje się nie znać naukowych procedur badawczych, o czym świadczy następujący cytat: „Dość kuriozalnie brzmi ostatnie zdanie tego rozdziału, w którym autor napisał, że takie właśnie modelowe ujęcie polityki zagranicznej »umożliwia identyfikację problemu badawczego, zadanie adekwatnych pytań badawczych i udzielenie na nie odpowiedzi w formie hipotez wydedukowanych $\mathrm{z}$ teorii polityki zagranicznej« [...]. Hipotezy nie są odpowiedzią, a ich sprawdzenie wymaga kontaktu z rzeczywistością, a nie dedukcji z teorii, której nie ma”. Zaraz potem Recenzent przeczy sobie, pisząc: „Wszak zarówno autor tego rozdziału, jak i pozostali autorzy odwołują się przede wszystkim do różnych teorii stosunków międzynarodowych, a nie polityki zagranicznej, co jest niefortunną konsekwencją przypisania monopolu badania tej drugiej przez te pierwsze". Z recenzji Profesora Kuźniara wynika niezbicie, że nie dostrzega on różnicy między teorią a metodologią. Przykładem tego fundamentalnego błędu jest jego opinia o rozdziale na temat interpretatywizmu: „W rozdziale w najmniejszym stopniu nie odniesiono się ani do badania stosunków międzynarodowych (ich metodologii), ani do polityki zagranicznej. [...] w całości jest poświęcony interpretatywizmowi w kategoriach filozoficznych i nie daje szans na jego operacjonalizację w odniesieniu do problemu, o którym mówi tytuł książki”.

Profesor Kuźniar jako recenzent ma wyraźny kłopot z właściwym usytuowaniem badania polityki zagranicznej w naukach społecznych w ogóle, ponieważ na przemian stwierdza, że należą one do nauk politycznych, stosunków międzynarodowych lub stosowanych nauk społecznych. Dowodzi to braku znajomości stanu badań na świecie. Należy tu przypomnieć, że w strukturze International Political Science Association (IPSA) nie ma komitetu ds. badania polityki zagranicznej. Jednostka taka funkcjonuje w ramach International Studies Association (ISA), który wydaje wpływowe czasopismo „Foreign Policy Analysis". 
Kolejną kwestią budzącą ogromne zdumienie jest opinia Profesora Kuźniara, że autorzy pracy nie zetknęli się z praktyką polityki zagranicznej i przez to nie są w stanie zweryfikować swoich poglądów. Odrzuca tym samym potrzebę empirycznej weryfikacji w oparciu o uznane procedury naukowe. To propozycja powrotu do znanych z przeszłości praktyk, kiedy o kryteriach naukowości decydowali ideolodzy i politycy. Taka postawa Recenzenta wydaje się zrozumiała, jeśli weźmie się pod uwagę Jego niegdysiejszą fascynację ideologią marksistowsko-leninowską w okresie PRL-u².

Wymienionych wyżej błędów w recenzji z pewnością dałoby się uniknąć, gdyby jej Autor zapoznał się z procedurami teoretyzowania i postępowania badawczego zawartymi chociażby w takich opublikowanych w języku polskim monografiach jak Struktura teorii stosunków międzynarodowych Kennetha Waltza ${ }^{3}$ czy Realizm w nauce o stosunkach międzynarodowych Stefano Guzziniego ${ }^{4}$. Znając je, z pewnością nie formułowałby w końcowej części recenzji opinii o bezcelowości teoretyzowania, które jakoby prowadzi na poznawcze manowce.

Należy zauważyć, że w recenzji ocenione zostały tylko niektóre rozdziały pracy, bez podania żadnego kryterium ich wyboru. Poddając krytyce rozdział autorstwa Aldony Tomczyńskiej, Recenzent nie odnosi się do zaproponowanej metody weryfikacji hipotezy, tj. oceny jej poprawności pod względem logicznym i merytorycznym (dobór danych empirycznych), ale skupia się na krytyce autorki, posługując się sloganem propagandowym Donalda Trumpa (o statusie fake news), jakoby USA traciły na relacjach handlowych z Chinami. Jest to argument publicystyczny, który ma niewiele wspólnego z analizami ekonomistów i think tanków na temat amerykańsko-chińskich relacji ekonomicznych.

Oceniając rozdział poświęcony teorii kodu operacyjnego, Profesor Kuźniar wykazał się całkowitym brakiem znajomości jej zalet i ograniczeń poznawczych, udokumentowanych w bogatej literaturze przedmiotu, którą wypadałoby na tę okoliczność zacytować. Zamiast tego ucieka się w swej ocenie do publicystycznej i banalnej formuły, że w badaniach polityki zagranicznej należy uwzględnić wartości, idee, percepcję, tradycję itp. To elementy wiedzy potocznej, która w żaden sposób nie pomaga w wyjaśnianiu związków

2 Zob. tenże, System zachodni w stosunkach międzynarodowych. Czynniki sprawcze ewolucji, COMSNP, Warszawa 1990.

3 K. N. Waltz, Struktura teorii stosunków międzynarodowych, przeł. R. Włoch, Wydawnictwo Naukowe „Scholar”, Warszawa 2010.

4 S. Guzzini, Realizm w nauce o stosunkach międzynarodowych, przeł. S. Szymański, Wydawnictwo Naukowe „Scholar”, Warszawa 2017. 
przyczynowo-skutkowych w polityce zagranicznej, a przecież od recenzenta z tytułem naukowym mamy prawo wymagać znajomości teorii i modeli, które te związki objaśniają.

Ocena rozdziału na temat polityki zagranicznej PRL potwierdza także, że Recenzent nie zna reguł dyskursu naukowego. Zamiast merytorycznego odniesienia się do postawionych przez autorkę pytań badawczych znajdziemy tam bowiem lekceważącą opinię, że mają one wartość jedynie dla historyków, a nie dla badań współczesnej polityki zagranicznej. Myli się w tym względzie zasadniczo, ponieważ historyczne studia przypadku ułatwiają testowanie teorii polityki zagranicznej, a archiwa oferują najlepszy dostęp do danych empirycznych.

Wyjątkowo kompromitującym elementem recenzji jest próba zdezawuowania tytułu i treści rozdziału pt. Specyfika polityki zewnętrznej UE - wymiar empiryczny i teoretyczny. Oto co pisze na ten temat Profesor Kuźniar: „Pomijam fakt, że sam termin jest nieprecyzyjny, gdyż w UE wyróżnia się politykę zagraniczną, bezpieczeństwa i obrony oraz odrębnie stosunki zewnętrzne". Sformułowanie to dowodzi poważnej luki w stanie wiedzy Recenzenta o istocie stosunków zewnętrznych UE, które klasyfikuje jako odrębne od wspólnej polityki zagranicznej i bezpieczeństwa, wspólnej polityki bezpieczeństwa i obrony, nie mówiąc już o pozostałych działaniach zewnętrznych wymienionych w części piątej Traktatu o funkcjonowaniu UE. To fundamentalny błąd merytoryczny. Należy przypomnieć, że czwarty rozdział Traktatu o UE noszący tytuł Postanowienia ogólne o działaniach zewnętrznych tworzy normatywną bazę dla wszystkich form zewnętrznej działalności UE, w tym wspólnej polityki zagranicznej i bezpieczeństwa, wspólnej polityki bezpieczeństwa i obrony, wspólnej polityki handlowej, pomocy rozwojowej i innych.

Wybiórcza ocena tylko niektórych rozdziałów to jedno, ale Profesor Kuźniar obraża przy tym autorów, kwestionując ich podmiotowość i suwerenność badawczą; pisze bowiem, że sugerowali się definicjami redaktora tomu. Odmawia im także prawa doboru narzędzi badawczych i teorii.

$\mathrm{Na}$ koniec należy zauważyć, że Recenzent nie jest początkującym badaczem, ale osobą z tytułem naukowym, członkiem Senatu Uniwersytetu Warszawskiego, a ponadto przewodniczącym Rady Naukowej Instytutu Stosunków Międzynarodowych UW. Nie dziwi zatem, że uczelnia mająca w swoich władzach naukowców o tak niskich kompetencjach w dziedzinie metodologii nauk społecznych od lat niezmiennie zajmuje miejsce w czwartej setce uniwersytetów na świecie. 